\title{
THE BENCH, BAR AND COURTS IN BENTON COUNTY
}

\author{
By J. F. Traer
}

When one attempts to write the early history of Iowa he is badly handicapped. There are few old newspaper files, because there were few newspapers and records are fragmentary or non-existent. Traditions are abundant, but should be sifted with care. Old settlers are prone to boast, and with age the imagination becomes more vivid. Few officers are good record keepers. They are elected, not for their qualifications, because they are likable fellows, they were soldiers, they need the job, etc. Politics is a game that is played more for the joy of winning than for the good of the people.

Records accumulate and filing facilities are poor. They get piled up in corners or cupboards without system. Years ago Benton county's records overflowed the courthouse. A large vault was built west of the courthouse and connected by a covered passageway or hall. In this the records of several offices were mingled. Searchers combed them over for what they wanted and were not careful to put things back where they found them. At one time the supervisors hired a man to sort and classify this material. He spent the summer in that vault. Then the process was repeated. After the present courthouse was built things were better for awhile. But now again we are crowded. It is a safe bet that the present officers know nothing about the probate court or the county court. Probably most of the lawyers know as little.

Benton county was organized in 1846 and was attached to Linn county for judicial purposes, becoming a part of the Fourth district. Commissioners were appointed to select a county seat and they selected the $\mathrm{NE}^{1 / 4}$ of Sec. 21-85-10, which now lies within the limits of Vinton. Just why they made this selection is not known. It was not materially different from any other spot of ground, 
and it did have some disadvantages. It did not abut the river, and at that time people expected to travel the river. It had no water, a prime necessity. It was still government land, but had been selected as a part of the 500,000 acre grant for school purposes. That selection was not approved until January 11, 1851. So far as can be found Benton county never had title to any part of it. Did the county build a courthouse on land they did not own?

It is said that a town named Northport was platted, but the plat was never recorded. Later the county commissioners (supervisors) platted a town which they called Vinton. This is merely a map consisting of nine blocks with a public square in the center, but you cannot tell where this plat was situated. The records show that court was held in the courthouse in Vinton in 1848. Did the fact that two of the commissioners afterward acquired title to this quarter have anything to do with this selection? It is all very confusing and smells.

However, this location was unsatisfactory and an election for a relocation was held in April, 1849. The vote was a tie. The contest was between a location which is now the middle portion of the business section of Vinton and a site about three miles northeast, now in the middle of a farm.

\section{EARLY COURTHOUSES LOCATED}

The second election resulted in the selection of the present site. That fall James Leverich platted a town on this site which he called Fremont. The government would not accept that name for the postoffice, as they already had one town of Fremont in the state. They named the postoffice Vinton. No cause for this name is found in the postal records, but tradition says that it was so named in honor of a congressman from Ohio. Later the general assembly changed the name of Fremont to Vinton.

There is nothing but tradition as to the courthouse on Section 21. An early history of the county 
says that it was ordered built in Northport. It was to be of hewed logs, 20x24 and two stories. When Fremont was platted the present site of the courthouse was designated as "Public Square". There was no dedication for courthouse purposes, but the county took possession and built thereon. At the time of the erection of the present building this condition was noted, and the authorities thought it necessary to bring an action to quiet the title in the county.

The first courthouse on this site was a two-story frame structure and was said to have been situated in the southeast corner of the square. This must have been built in the very early fifties. It burned in January, 1853. The clerk and the recorder were sleeping in the building and saved the records by throwing them out the windows. The stairway was outside and was enveloped in flames. The officers came down a plank put up by the bystanders.

The next building was a two-story brick in the center of the square. It was about $40 \times 60$ and had the conventional cupola. By 1870 this building was badly outgrown and this was remedied by building a two-story addition across the front. This furnished four additional large rooms. A large vault was built to the west and joined to the main building.

With this we were able to get along until about the turn of the century. Three times was the proposition to issue bonds and build submitted and each time it was defeated. The people just could not see the big debt and interest payments for twenty years. A petition to relocate the county seat was circulated, but nothing came of that. It was looked upon as an effort to shake down Vinton for a large donation. Then some fertile-minded fellow suggested that we did not need to borrow money, that we could levy a tax and pay for the house as it was built. It was figured out that a five-mill levy for two years would do the job. Thus each taxpayer could know in advance just what it would cost him and just when he would have to pay it. The individual share was not 
enough to scare many. This proposition was submitted and easily carried. And now this house is nearly outgrown. The name of this benefactor is not known but he deserves a monument.

\section{The Courts Are Designated}

We have told about courthouses; now let us tell about courts.

The constitution provides that the judicial power shall be vested in the supreme court, the district court and such other and inferior courts as the general assembly may provide.

In the beginning we were put in the Fourth district. Then about 1858 we were moved into the Eighth district along with Linn, Johnson, Tama, Jones and other counties. In 1886 the districts were readjusted and Benton and Tama were made the Seventeenth district and were allotted one judge. Later, about 1896, Marshall county was put in the district and we were given an additional judge.

Let us take the inferior courts first. The justice court has always been with us, and frequently it is the last step down for some elderly man, not necessarily a lawyer. In the early days it had much business of a trifling nature, but lawyers frequently spent much time there and for small compensation. It is probable that they seldom received as much as $\$ 10$ for a days work. Its civil business has dwindled to almost nothing, but it handles many cases of petty misdemeanors.

Many of these justices were quaint characters and many tales are told of their decisions. Old Squire Kirkpatrick had a deep and genuine hatred for the supreme court and its decisions. He said one day that if they would take all the books that the lawyers called authorities and burn them the world would be better off. $\mathrm{He}$ decided things as he thought they should be, not necessarily what the books said. His decision in the famous "watermelon case" is a classic in Vinton. It was like this. Old man Hahn had Frank Thayer arrested for 
stealing a melon from him on the fairgrounds. Frank did not have a high standing in the community and he could not get a lawyer to defend him. He asked one of his mates to go along and help. As a matter of fact Frank had not stolen the melon. Another fellow had stolen it and slipped it to Frank and he made the "get away". They badgered the witnesses and browbeat the squire until they ran out of wind and sat down to await his decision. In early life the squire had an unsuccessful encounter with a dentist and the dentist had gotten quite a part of his jaw bone, so that his mouth was well to one side rather than in front and he creaked rather than spoke. He chewed slippery elm instead of tobacco. He chewed and pondered. Finally he said, "Well, Frank, there aint a bit of doubt in my mind that you got that melon, but they have not proved it on you and I am going to let you go".

The probate court was what its name indicated. The county court followed the probate court. It was established by the code of 1851 . The judge was really the court and frequently he was very much of a dictator. It had supervision of town plats and the incorporation of towns and the vacation of plats; it could issue licenses for internal improvements, as dams, toll bridges, canals, etc; it had supervision of the poorhouse and poor relief; the care of the insane; bastardy proceedings; lost goods; it could issue marriage licenses; it had charge of all probate matters and guardianships.

The clerk of the district court was the clerk of the county court, but was required to keep separate records. The judge also performed many of the duties of the county auditor. This court was abolished in 1869. G. M. Gilchrist was the last county judge and became the first county auditor. This is where he really acquired his title, although he was afterward a district judge.

\section{CIRCUIT COURTS UNPOPULAR}

By 1870 the district court was well nigh swamped with business, and the then state of the constitution would 
not admit of the creation of additional districts fast enough to take care of the additional business. The circuit court was established as an inferior court. Each district was divided into two circuits and each circuit had a judge. It had the probate jurisdiction and appellate jurisdiction on appeals from justice courts. It had no criminal jurisdiction save on appeals from justice courts. Cases might be transferred to or from the district court by consent of parties. Then there was a general term session when the two circuit judges sat with the district judge to hear appeals from the circuit court. From such session there was still the appeal to the supreme court. This arrangement proved unpopular and the provision was repealed at the next session of the assembly and the right of appeal direct to the supreme court was restored.

There were but two terms of the circuit court per year. At that time the jury came the first week of the term and it tried July cases for three weeks. The fourth week was spent in finishing up and the court then adjourned. It was a long time between terms and much different from the present custom of prolonging the term until the next is ready to begin.

In 1886 the constitution was amended to permit the assembly to establish additional districts at will and the circuit was abolished. At this time the office of district attorney was abolished and the county attorney system was established.

Five men served as judges of the circuit court. First was William E. Miller of Iowa City. He resigned to go on the supreme bench. Next was G. R. Struble of Toledo. He served a few months and resigned. Third was William J. Haddock of Iowa City. He also served only one year. Next came John McKean of Anamosa. He served from 1872 until 1881. The last was Christian Hedges of Marengo. He served from 1882 until the court was abolished in 1886 . 


\section{THE District COURT JUdiciaRY}

And last but not least the personnel of the district judges. The first was James P. Carleton of Iowa City. He was judge when the county was established.

The first term of court was held in 1847, at the home of Tom Way, about three miles northeast of Vinton. Just why it was held there is not apparent, for that was not the county seat. Routine business was transacted. William Smyth of Marion was admitted to practice. He was afterward to be a judge of this court, to command a regiment in the Civil war and to be a member of congress.

The acting prosecuting attorney applied for admission, but they "plucked" him and removed him from office.

Later the record shows that court was held in the courthouse in Vinton. This must have been the courthouse on Section 21.

The third was Isaac Cook of Marion who served during 1857-8.

Next came William E. Miller of Iowa City who served in 1859-60-61. Judge Miller compiled an annotated code of Iowa which was in use in the eighties.

Fifth was Norman W. Isbell of Marion who served in 1862-4-5. Judge Isbell had previously served on the supreme court in 1855-6.

Sixth was Charles H. Conklin of Vinton who served during 1864-5. He found that he could not live on the salary and resigned. Others found that out also.

The seventh was N. M. Hubbard of Cedar Rapids who served in 1865-6. He resigned to become attorney for the Northwestern railroad. He was famous throughout Iowa as a railroad attorney and political dictator.

The eighth judge was James $H$. Rothrock of Tipton, later of Cedar Rapids. He served from 1866 until 1876 when he went on the supreme bench. 
John Shane of Vinton was the ninth judge, appointed to the Rothrock vacancy. He was elected for a full term and had been nominated for another term in 1882. He suffered a stroke that summer and was compelled to resign the nomination. He was incapacitated but lived until 1899.

J. D. Giffin of Marion was elected in 1882 and served four years. The districts were readjusted in 1886 and the Benton-Tama district was formed.

The first judge of the Benton-Tama district was L. G. Kinne of Toledo. He was elected in 1886 and served until 1889, when he resigned and went to Des Moines to edit the Des Moines Leader, the organ of Democracy in Iowa. G. M. Gilchrist of Vinton was appointed to the vacancy and served until the next election. In the meantime Judge Kinne's newspaper venture had proved unsatisfactory and he again became a candidate for the judgeship. He defeated Judge Gilchrist and was later re-elected for a full term, and in 1891 he was elected to the supreme bench.

John R. Caldwell of Toledo was appointed to the vacancy and later elected for the short term.

In 1896 G. W. Burnham of Vinton was elected and served twelve years.

\section{Judges of Present District}

In 1896 Marshall County was added to the district and we were given a second judge. Obed Caswell of Marshalltown was appointed and he served ten years.

In 1906 John M. Parker of Marshalltown was elected to succeed Judge Caswell and he served four years. At the same election C. B. Bradshaw of Tama defeated Judge Burnham and he served eight years.

In 1910 Clarence Nichols of Vinton was elected and served until 1914, when he resigned to re-enter practice. B. F. Cummings of Marshalltown was appointed to the vacancy and at the fall election was elected to the full 
term. He served until 1930. Also in 1914 James W. Willett of Tama was elected and served until 1926.

In 1926 Clarence Nichols of Vinton was again elected and served until 1933, when he resigned. C. B. Stiger of Toledo was appointed to this vacancy and he served until 1936 when he went on the supreme bench. C. E. Walters of Tama was appointed to the vacancy and served until the election when he was defeated by L. J. Kirkland of Vinton. Judge Kirkland resigned in 1942 and B. F. Thomas of Traer was appointed and is still serving.

In 1930 B. O. Tankersley of Marshalltown was elected and is still serving.

Prior to 1886 we had a district attorney who conducted all criminal prosecutions. Among these can be remembered I. M. Preston, Milo P. Smith and J. H. Preston of Cedar Rapids and W. G. Thompson of Marion. All were able lawyers and vigorous prosecutors. Thompson, Smith and J. H. Preston were Civil war soldiers.

The county attorney's office was generally passed to some of the younger members and nearly all of our members served when they were young.

\section{LYNCHINGS AND WHIPPINGS}

Settlers came before the courts and it was necessary for them to protect themselves and settle their differences. Many settled them fist and skull. There are tales of whipping, tar and feathers, banishment, etc. Probably some of these are true. Probably some of the victims got what was coming to them or maybe only a part of it.

The most famous, or notorious, case of lynch law was the case of John Mason. This occurred in the summer of 1878. Mason was said to be a man of wholly bad character and was unwelcome in Benton township. In fact he had been urgently invited to stay away. Nevertheless he drove into that township one Sunday morning in June. At one point he saw something which aroused his suspicions. He got out to investigate and was shot 
down, but not killed. He was taken to a farm house and put in bed. While two men watched, another went for a doctor. As they waited, a band of masked men came into the room and fired a volley into Mason. That did kill him. The coroner was notified and the body brought to Vinton and laid on a bench in the courthouse yard. $\mathrm{He}$ was a gruesome sight. One small boy returning from the swimming hole viewed the remains and he has not forgotten the sight.

Eight men were indicted for murder and were tried the next spring. The trial lasted a number of days and three were convicted of manslaughter and were sentenced to three, six and nine months in the penitentiary. None of them served his sentence and all were afterward pardoned. While it was conceded that their acts were irregular, it was felt that they had done the community a service.

Another case of lynching, only attempted, was the Big Grove "White Cap" case. A young man named Bean had gotten into difficulty with an old lady and gave her a pretty thorough beating. However, he knew that he had been in a fight. He was bound over to the grand jury, but some of the hotheads thought that the law would be too slow and organized a party to call on Bean and reason with him. Just what they intended to do was never apparent. One old pacifist was invited to go along but declined with thanks. He got word to Bean to expect company. Bean and his brother took some iron rods off the corn plow and went to bed with them. Their father lay down on the parlor floor with a pitchfork at hand. The hotheads evidently knew the house. The main door opened at the foot of the stairs. They kicked in the door and swarmed up the stairs. The boys laid about them with their rods and the old man attacked the rear with his fork. In no time at all there was an old fashioned "hell of a time" in progress. One of the regulators drew a revolver and fired. He hit one of his mates in the arm. The crowd was beaten back and left. It is not remembered that they left any wounds 
on the young men. The old man insisted that he had jabbed a man in the neck with his fork, but no man could be found with a wound in his neck. It was a three-tined fork with the middle tine broken out, so we must assume that he merely straddled his neck. The wounded man had to come to town for medical attention and the sheriff picked him up at once. Then he went out and arrested most of the young men in the neighborhood and some that had ceased to be young. The suspects immediately employed counsel and were given good advice. "Keep your mouths shut". Always good advice. They did not talk then or afterward. Even fifty years later they would not talk. A number were indicted and after argument plead guilty to a charge of riot. They were given fines running up to $\$ 200$ and a day in jail. A wholly inadequate punishment. The young man was fined $\$ 250$ for beating the old lady.

\section{The Novak MURDeR CASE}

Of all murder cases tried in this county probably the Novak case attracted the most attention. Briefly the facts were these. Novak was running a large store at Walford. He was doing a big business and was supposedly prosperous; but assets show, while liabilities are not so plain. He was heavily insured both as to property and life. He was accustomed to sleep in the store. One night in February, 1897, the store burned and the remains of a man were found in the ruins. For a while this was presumed to be Novak, but another man was missing and he had been with Novak the night before. It was determined that the remains were those of Ed Murray. Novak had disappeared and search failed to find him.

But the insurance companies had not forgotten. Late in August a detective landed in Seattle with Novak in custody. He had traced him to the British Northwest Territory, had extradited him and got back to the United States without publicity. Novak was placed in the jail and was indicted for murder. M. J. Tobin was county 
attorney at that time and was assisted by Louis Boies of Waterloo. Tom Milner of Belle Plaine and J. J. Ney of Iowa City defended. The trial lasted a number of days and was a hard fought battle. The jury brought in a verdict of second degree murder and recommended the minimum punishment. That was none of their business. Judge Burnham overruled the motion for a new trial and sentenced Novak to life imprisonment. Some ten years later Governor Cummins pardoned him. $\mathrm{He}$ died very shortly after that. There have been a number of murder trials in the county most of them resulting in acquittals. Never has a man been sentenced to death in this county.

There have been many civil cases, but few of outstanding interest. The famous "Jones County Calf Case" was tried here on change of venue.

Quite a few important cases were brought from Tama county. Notably was a malpractice suit brought against a doctor in Traer. In this case the plaintiff's lawyers made the mistake of allowing on the jury a man who had two sons who were physicians. Of course that jury disagreed.

Another case from Tama county was that of Mike Casey for damages for injuries received when a bridge broke down with Casey crossing it. All the big lights of the Tama bar were present, as well as Colonel Clark of Cedar Rapids, who assisted the county attorney in the defense. On direct examination Mr. Casey testified that immediately after the accident his feet got as cold as ice and had been getting colder ever since. When the colonel took him on cross examination he thought he was going to make a monkey of Mike. He did not. The examination was about like this.

Colonel Clark: Mr. Casey?

Casey: Yis, Sorr.

Clark: You say that immediately after this accident your feet got as cold as ice? 


\section{Casey: Yis, Sorr.}

Clark: And that they have been getting colder ever since?

Casey: Yis, Sorr.

Clark: Mr. Casey, will you tell the jury how cold they are now?

Casey: Shure, they're cowled enough, God knows.

And even the judge laughed and the bailiff only made a token effort at restoring order.

\section{FEWER JURy TRIALS}

The trial of jury cases has largely gone out of fashion in this county. Frequently we have a term without jury trial. Evidently people go to lawyers for counsel rather than for conflict. And if they only knew it they can better afford to pay a lawyer a big fee for keeping them out of trouble rather than taking them through it.

The standing of the Benton county bar has been high. We have never disbarred a member, but sometimes have welcomed a removal from the county and a few have been tactfully advised to surrender their certificates.

James Wood, one of the earlier members spent most of his life as a justice of the peace. He compiled a form book for the use of justices and constables which with some revisions is still in use.

The older members always spoke of Charles $\mathrm{H}$. Conklin as the most brilliant of them, but they did not cite any famous cases tried by him. He wrote a book, "Iowa Justice", but no one now possesses a copy of it.

In his time, 1872-1913, J. D. Nichols, Sr., was one of the outstanding lawyers of Benton county. He grew up in the time when men largely settled their differences with their fists. To him a lawsuit was a fight with no holds barred. He took his client's trouble as seriously as did the client. He could honestly get wrought up to tears. (Dave Voris spoke bitterly of Nich's "crocodile tears.") He was somewhat boastful and liked to try 
his cases to the public as well as to the jury. He was given to telling what he would do to his opponent in the trial. Sometimes this backfired. Generally he was on one side or the other of all the big cases. He was very successful, but became incapacitated and lived a long time in retirement. His son, Clarence Nichols, was for many years a very capable lawyer and enjoyed a large practice. His grandson, J. D. Nichols, Jr., gave promise of a successful career, but died early.

M. J. Tobin was a trial lawyer of note and enjoyed a good fight. He had many of them and was very successful.

It must not be assumed that because only a few are mentioned by name that they are the only ones who did anything. Our lawyers were of the general run of Americans; some were very able; some less so, and some not at all. In an article like this it is impossible to mention all. They served their clients. They served their country in civil life and in the armed forces.

In the Civil war were W. C. Gaston, John Shane, G. M. Gilchrist, John D. King, George W. Sells, H. E. Warner, S. P. Vanatta, Milton Worth, Thomas Drummond, P. H. Lynch, B. R. Sherman, Alfred Haines, F. G. Clark, and Jacob Wetz. Drummond was killed and Worth died in the service.

In the Spanish-American war were Guy Kellogg and George E. Knapp. Kellogg died in the service.

In the first World war were J. H. Milroy, Hamilton Tobin, John W. Tobin, Louis P. Tobin, Karl W. Fischer, J. D. Nichols, Jr., Charles E. Hughes and V. D. Vifquain.

In the second World war were Karl W. Fischer, John F. Scott, Robert W. Scott, M. H. Bordewick, Don Boddicker, Frank Baird, Wallace F. Snyder, Harold Swales, and Keith Mossman. Snyder was killed.

The Benton County Bar Association was organized in 1928 and numbers in its membership nearly all of the practicing lawyers. They meet for discussion and join 
with Tama and Marshall counties in legal institutes. At this time $\mathbf{M}$. H. Bordewick is president and Keith Mossman is secretary.

One of the projects of our association has been to acquire the portraits of all of the judges who have served in this county. In this we have been successful in acquiring all of these except that of James P. Carleton, the first judge. These portraits will hang in the judges rooms in the courthouse.

Among those who practiced in the county for a long time may be mentioned W. C. Connell, John Shane, John McCartney, J. C. Traer, J. D. Nichols, Sr., G. W. Burnham, W. P. Whipple, Clarence Nichols, L. J. Kirkland, Hugh Mossman, Charles F. Stookey, Charles I. Vail, P. H. Lynch, J. J. Mosnat, George C. Scrimgeour, W. C. Scrimgeour, M. J. Tobin, maybe others.

A roster of all the men who have been admitted or have practiced in the county is in preparation and will be filed in the county clerk's office and in the library. It will contain over 160 names.

The present members of the bar are L. J. Kirkland, J. W. Tobin, J. H. Milroy, J. F. Traer, Karl W. Fischer, John F. Scott, Robert W. Scott, Frank Baird, Don Boddicker, Keith Mossman, Hugh Mossman, M. H. Bordewick, Edward F. O'Conner, all of Vinton and V. D. Vifquain, Charles E. Hughes, H. R. Mosnat, C. E. Hutchens and Harold Swales of Belle Plaine. Charles F. Stookey, a long-time resident of Shellsburg, is living in retirement in Bettendorf, Iowa.

\section{FOUR GREAT BENEFITS TO MANKIND}

The assembling of an alphabet, the invention of the printing press, the construction of the wheel and the discovery of fire, constituted four great primary benefits to mankind that have continued to bless the human race even to this day. 
Copyright of Annals of Iowa is the property of State of Iowa, by \& through the State Historical Society of Iowa and its content may not be copied or emailed to multiple sites or posted to a listserv without the copyright holder's express written permission. However, users may print, download, or email articles for individual use. 